\title{
The mTOR Pathway in Breast Cancer
}

\author{
Nancy E. Hynes • Anne Boulay
}

Published online: 9 August 2006

(C) Springer Science + Business Media, Inc. 2006

\begin{abstract}
There is currently a wealth of information regarding the mutations that contribute to cancer development. Most of these mutations alter the expression and activity of signal transduction proteins. The current goal in cancer therapy is to use our knowledge of the molecular alterations in a cancer cell to choose the most appropriate signal transduction inhibitor for an individual patient. The topic of this review is the mammalian target of rapamycin (mTOR) kinase signaling pathway, which is aberrantly activated in many types of human cancer. We will discuss the mTOR pathway and the potential mechanisms that contribute to its activation in cancer, together with data relating to the potential for inhibitors targeting the mTOR-signaling pathway to impact on breast cancer therapy.
\end{abstract}

Keywords mTOR $\cdot$ Breast cancer Translational control . $\mathrm{PI} 3 \mathrm{~K} \cdot \mathrm{LKB} 1 \cdot \mathrm{AKT}$

$\begin{array}{ll}\begin{array}{l}\text { Abbreviations } \\ \text { AMPK }\end{array} & \begin{array}{l}\text { AMP- activated protein kinase } \\ \text { chronic myelogenous leukemia }\end{array} \\ \text { CML } & \text { eukaryotic initiation factor 4E } \\ \text { eIF-4E } & \begin{array}{l}\text { estrogen receptor } \\ \text { ER }\end{array} \\ \text { FGFR } & \text { fibroblast growth factor receptor } \\ \text { FKBP12 } & \begin{array}{l}\text { FK506-binding protein-12 } \\ \text { farnesyltransferase inhibitor }\end{array} \\ \text { FTI } & \text { hypoxia inducible transcription factor } \\ \text { HIF } & \text { human mammary epithelial cells } \\ \text { HMEC } & \text { insulin like growth factor-1 receptor } \\ \text { IGF-1R } & \begin{array}{l}\text { loss of heterozygosity } \\ \text { LOH }\end{array} \\ \text { mTOR } & \text { mammalian target of rapamycin }\end{array}$

N. E. Hynes $(\bowtie) \cdot$ A. Boulay

Friedrich Miescher Institute for Biomedical Research, Maulbeerstrasse 66,

CH-4058 Basel, Switzerland

e-mail: Hynes@fmi.ch
PDK1 phosphoinositide dependent protein kinase 1

$\mathrm{PH} \quad$ plekstrin homology

PIKK phosphoinositide kinase-related kinase

PIP3 phosphatidylinositol-3,4,5 triphosphate

PI3K phosphoinositide 3-kinase

PJS Peutz-Jeghers syndrome

PKB protein kinase B

PTEN phosphatase and tensin homologue deleted in chromosome 10

RTK receptor tyrosine kinase

STI signal transduction inhibitor

S6K1 ribosomal S6 kinase

TKI tyrosine kinase inhibitor

TSC tuberous sclerosis complex

4E-BP1 eukaryotic initiation factor 4E-binding protein 1

\section{Introduction}

The current goal in cancer therapy is to define the molecular alterations underlying the malignant phenotype. With a better description of these it should be possible to choose the appropriate signal transduction inhibitor (STI) for an individual patient. The topic of this review is the mammalian target of rapamycin (mTOR) kinase signaling pathway, which is aberrantly activated in many types of human cancer. TOR was originally identified by genetic means in the budding yeast Saccharomyces cerevisiae as the target of the macrolide antibiotic rapamycin [1]. Rapamycin is a potent suppressor of the immune system [2,3] and some of its analogues are currently under intense study as anti-cancer agents (reviewed in $[4,5]$ ). We will discuss the mTOR pathway and the potential mechanisms that contribute to its activation in cancer, together with data relating to the potential for STIs targeting the mTOR-signaling pathway to impact on cancer therapy. 


\section{mTOR}

mTOR is a member of the phosphoinositide kinase-related kinase (PIKK) family consisting of large serine/threonine kinases including ATM, ATR and DNA-PK, all involved in stress checkpoint control [6]. mTOR is a central regulator of cellular responses to multiple stimuli including amino acid availability [7], energy and oxygen stresses [8, 9] and growth factor receptor signaling [10]. In cells with sufficient nutrients, mTOR relays a signal to the translational machinery leading to an enhanced translation of mRNAs encoding proteins essential for cell growth and cell cycle progression (reviewed in [4, 11]). These functions are specifically mediated by the mTOR-Raptor (also named mTORC1) complex comprising the regulatory protein $\mathrm{G} \beta \mathrm{L}$ and Raptor; Raptor being suggested to function as an adaptor to recruit mTOR substrates [12-14].

mTOR has also been identified in a second complex containing the Rictor protein $[15,16]$. The mTOR-Rictor complex controls actin cytoskeleton organization. Moreover, mTORRictor has been described as a potential kinase for Ser473 in the hydrophobic regions of the Akt/PKB serine/threonine kinase [16]. mTOR-Rictor regulation and functions are still poorly understood and will not be further addressed in this review.

\section{mTOR Effectors}

The mTOR-Raptor complex signals directly to important translational regulators, the translational repressor protein eukaryotic initiation factor $4 \mathrm{E}$ (eIF-4E)-binding protein 1 (4E-BP1) and ribosomal S6 kinase (S6K1). Binding of 4EBP1 to eIF-4E is controlled by mTOR dependent phosphorylation of specific serine and threonine residues [17]. Once 4E-BP1 is completely phosphorylated [18], it dissociates from eIF-4E allowing the formation of a translationally competent initiation factor complex eIF-4F [17]. eIF-4F activation results in translation of a subset of capped mRNA containing highly structured 5'-untranslated regions and encoding proteins involved in G1- to S-phase progression, such as c-myc [19] and cyclin D1 [20-22]. The second important mTOR target, $\mathrm{S} 6 \mathrm{~K} 1$, has been implicated in translational regulation of mRNAs with a 5'-terminal oligopyrimidine (TOP) tract such as those that encode ribosomal proteins, proteins involved in translation [23]. Considering the importance of the proteins that are subject to mTOR mediated translational control in cell proliferation and growth, it is not surprising that cancer cells undergo alterations that impact on mTOR activity.

\section{Uptream Activators of mTOR}

mTOR-Raptor is a component of a multisubunit complex that is controlled by inputs from two major sources, the phosphoinositide 3-kinase (PI3K) pathway, an important signaling module downstream of receptor tyrosine kinases (RTKs) [10] and the LKB1/AMP kinase (AMPK) pathway [24] (Fig. 1). PI3K activation following growth factor stimulation impacts on the $\mathrm{Akt} / \mathrm{PKB}$ serine/threonine kinase, while one of the major targets of the LKB1 serine/threonine

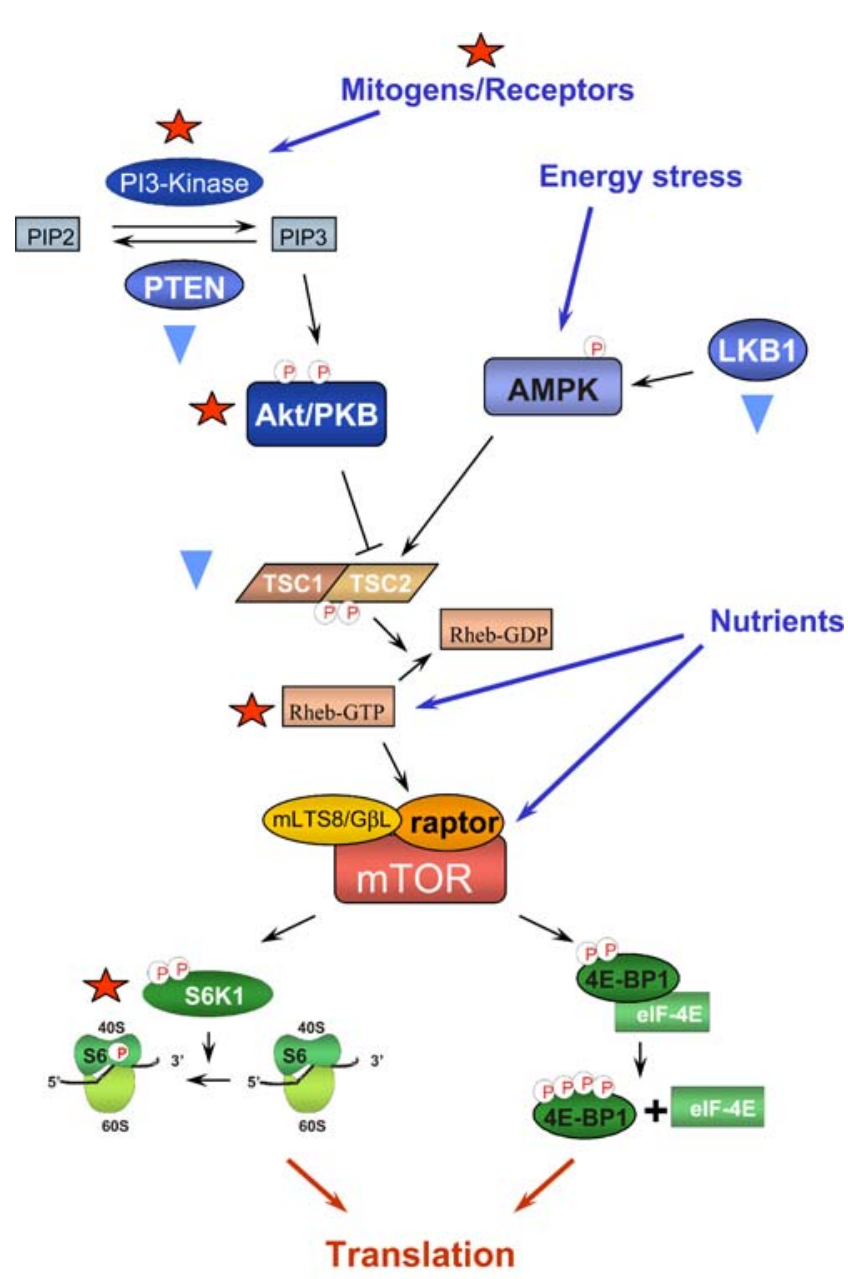

Cell growth and proliferation

Figure 1 Model of the mTOR pathway; its regulation and cancer specific alterations. mTOR lies at the interface of two major signaling pathways, one initiated by PI3K and the other by AMPK. Mitogen signaling to receptor tyrosine kinases activates PI3K and Akt, which phosphorylates TSC2 leading to activation of Rheb GTPase and mTOR activation. AMPK is a regulator of cellular energy metabolism. In the presence of high AMP, the AMPK gamma regulatory subunit binds AMP permitting the alpha subunit to be phosphorylated and activated by LKB1 kinase. AMPK in turn phosphorylates TSC2, strengthening the ability of the TSC complex to block Rheb GTPase activity and lowering mTOR activity. The red asterisk (*) indicates mutations leading to pathway activation in cancer. These include constitutive activation of receptor tyrosine kinases, overexpression or mutational activation of PI3K and Akt as well as overexpression of Rheb and S6K1. The inverted triange ( $\nabla)$ indicates proteins that are lost in cancer cells. These include PTEN, the negative regulator of $\mathrm{PI} 3 \mathrm{~K}$, TSC complex proteins hamartin and tuberin and the LKB1 kinase. 
kinase is AMPK, a master sensor of cellular energy supply [25]. Control of mTOR activity is quite complex, involving inputs from multiple regulatory proteins (Fig. 1) (Reviewed in $[4,11,26]$. We will discuss mTOR-Raptor control at the interphase of the PI3K and LKB1 pathways.

PI3K catalyzes production of phosphatidylinositol-3,4,5 triphosphate (PIP3) at the cell membrane, which in turn stimulates the recruitment and activation of the serine/threonine kinase Akt/protein kinase B (PKB), a major player on the pathway. Akt is a family member of the AGC (cAMP dependent, cGMP dependent and protein kinase $\mathrm{C}$ ) protein kinases. Binding of Akt's plekstrin homology (PH) domain to PIP3 is necessary for phosphoinositide-dependent protein kinase 1 (PDK1) phosphorylation of Thr308 in its activation loop. Complete Akt activation results from a second phosphorylation on Ser473 in the hydrophobic motif at its C-terminus [27]. At least ten protein kinases have been proposed to function as the second Akt kinase including mTOR-Rictor as mentioned above. This second kinase is often termed PDK2; this is currently an area under intense study. Nonetheless, it is likely that multiple upstream kinases can regulate Akt and other members of the AGC kinase family (reviewed in [28]). Once activated, Akt has multiple substrates, one of which is tuberin a protein directly involved in mTOR regulation.

Tuberin, also referred to as tuberous sclerosis complex (TSC) 2, together with hamartin, TSC1, form a heterodimeric complex that negatively regulates mTOR signaling [29]. Tuberin is a GTPase activating protein (GAP) for the Rasrelated GTPase Rheb (Ras homologue enriched in brain). Tuberin triggers the conversion of the active GTP-bound Rheb to the inactive GDP-bound form [30, 31]. Following tuberin phosphorylation and functional inactivation by Akt $[32,33]$, the negative effect of TSC on Rheb function is disrupted [30], and Rheb-GTP is formed. Various lines of evidence suggested that Rheb acted upstream of mTOR [34], and it is now known that Rheb binds directly to the kinase domain of mTOR, presumably enabling a conformational change in the mTOR-Raptor complex promoting its activation [35].

Turning to the other major pathway regulating mTORRaptor, the serine/threonine kinase LKB1 was originally identified in 1996 by Dr. J. Nezu as a novel mammalian kinase (discussed in [24]). Interest in the kinase increased dramatically when germline inactivating mutations in the gene encoding LKB1 (also known as serine threonine kinase 11) were shown to be responsible for the Peutz-Jeghers syndrome (PJS) [36, 37]. PJS is an autosomal dominant syndrome characterized by benign hamartomatous polyps in the gastrointestinal tract [38]. The LKB1 kinase has also been implicated in sporadic cancer (discussed below).

The LKB1 kinase is part of a regulatory complex that phosphorylates and activates AMP kinase (AMPK)-related kinase family members (reviewed in [24]). AMPK, a master regulator of cellular energy metabolism [25], is a heterotrimeric complex composed of a catalytic alpha subunit and beta and gamma regulatory subunits. In cells with a high AMP to ATP ratio, AMP binds the gamma subunit and induces a conformational change converting the alpha subunit into a substrate for LKB1 that phosphorylates AMPK alpha on a threonine residue in its activation loop [39]. AMPK activation causes numerous cellular responses, one of them being a decrease in energy-consuming processes such as protein synthesis, a response that connects AMPK to mTOR. Indeed it was shown that AMPK inhibits cellular proliferation under conditions of energy starvation by phosphorylating tuberin (TSC2) and enhancing the ability of TSC to block mTOR signaling [40].

In summary, the two major regulators of mTOR-Raptor activity, the PI3K/Akt and the LKB1/AMPK pathways, both impact on TSC. Phosphorylation of tuberin by Akt blocks the ability of the complex to interfere with Rheb activity, thus stimulating mTOR activity. In contrast, phosphorylation of tuberin by AMPK strengthens its GAP activity towards Rheb, thus resulting in a blockade of mTOR activation (Fig. 1).

\section{mTOR (dys)Regulation in Cancer}

The mTOR pathway is abnormally activated in many tumors. Multiple alterations, both upstream and downstream of mTOR, leading to pathway activation have been described (Fig. 1). In the following sections we will discuss the mechanisms and mutations that lead to deregulated mTOR activity in cancer, specific data on breast cancer will be mentioned where possible.

As discussed above two of the major mTOR substrates, 4EBP1 and S6K1 are directly involved in translational control of mRNA coding for important cell cycle regulators and cell growth regulators, for example, cyclin D1 and the ribosomal proteins, respectively. Considering that cancer cells are dependent upon many of these proteins for their malignant phenotype, it is not surprising that $\mathrm{mTOR}$ is considered to be a potentially important target for cancer therapy. A number of mTOR inhibitors, as well as inhibitors of proteins on the mTOR pathway, are in clinical development. We will end the review with a discussion on selected pathway inhibitors.

\section{Positive mTOR Regulators and Cancer}

A major mTOR regulator, the PI3K/Akt pathway, is aberrantly activated in most human tumors. Many human cancers have alterations in RTKs that promote constitutive activation of the PI3K/Akt pathway. Aberrant activation of the insulin like 
growth factor-1 receptor (IGF-1R) [41], the fibroblast growth factor receptor (FGFR) family $[42,43]$ and members of the epidermal growth factor receptor (EGFR)/ERBB family have been found in many human cancers. Considering breast cancer, approximately $20 \%$ of primary breast tumors overexpress the ErbB2 RTK due to gene amplification (reviewed in [44]). ErbB2-overexpressing tumors show high constitutive PI3K/Akt activity, mainly through coupling of ErbB2 to ErbB3 [45], a receptor with multiple binding sites for the p85 regulatory subunit of the PI3K [46]. Overexpression and activation of FGFR has been reported in breast cancer [42, 43] and has been linked to mTOR pathway activity [20]. The IGF-1R has also been implicated in breast cancer, which is a topic of another review in the issue (Sachdev and Yee).

Amplification and overexpression of the PIK3CA gene, encoding the $\mathrm{p} 110 \alpha$ subunit of the PI3K was found mainly in ovarian cancers [47]. More recently, somatic point mutations in the PIK3CA gene have been described in many types of human tumors [48]. Considering breast cancer, PIK3CA mutations have been detected in $25 \%$ of tumors [49], making this one of the most frequently mutated genes in this cancer. The biochemical and transforming activity of several $\mathrm{p} 110 \alpha$ mutants have been described $[50,51]$. Expression vectors for two of the most common $\mathrm{p} 110 \alpha$ mutations, Glu545Lys and His1047Arg, have been introduced into human mammary epithelial cells (HMEC); each mutant was transforming and its oncogenic potency correlated well with an enhanced level of pathway activity [51]. The impact of enhanced PI3K activity on mTOR was not described, however, it is likely that tumors expressing $\mathrm{p} 110 \alpha$ mutants maintain mTOR activity independent from exogenous growth factor signals.

Elevated Akt1 [52] and Akt2 [53] kinase activity have been observed in various human tumors, including breast cancer. Activating Akt2 kinase domain mutations (2/180 tumors) [54] and AKT2 gene amplification (2/146 tumors) have been described in a small percentage of colorectal cancers [54] and breast cancers (3/106 tumors), as well as a higher percentage of ovarian tumors (16/132 tumors) [55]. Thus, it appears that in breast cancer activating mutation in the catalytic sub-unit of PI3K are more prevalent than in the Akt kinase domain.

Rheb, the direct upstream activator of mTOR [34], has also been found to be overexpressed at the RNA level in many human tumors [56]. Elevated Rheb expression is likely to impact on mTOR, since it has been shown that overexpression of Rheb increases the activity of the mTOR effector protein S6K1 [34]. Moreover, the $S 6 K 1$ gene is amplified in approximately $9 \%$ of primary breast cancers [57], and elevated levels of S6K1 RNA are found in almost $40 \%$ of the tumors [58]. In summary, most of the positive regulators of mTOR activity have been found mutated and/or overexpressed in human breast cancer. The most common alteration found is activating mutations in the PI3K.

\section{mTOR Regulation and Tumor Suppressors}

There are three negative regulators of mTOR activity: phosphatase and tensin homologue deleted in chromosome 10 (PTEN), TSC and LKB1; all three have important roles in many types of human cancer. PTEN downregulates the PI3K pathway by dephosphorylating position D3 of PIP3 and thereby antagonizing PI3K function. PTEN activity is lower in many human cancers due to gene deletion, gene silencing or mutational inactivation. Mutations in PTEN are relatively rare in breast cancer $(5 \%)[59,60]$. However, loss of heterozygosity (LOH) $[59,61]$ and promoter methylation of the PTEN gene [62], leading to low PTEN levels [63], are more common $(\sim 30 \%)$ in breast cancer. A recent immunohistochemical analysis revealed that $26 \%(n=236)$ of primary breast cancers had low PTEN levels, which correlated with lymph node metastases and a worse prognosis [64].

Thus, in addition to activating PI3K mutations in breast cancer, PTEN, the negative regulator of the pathway is often down-regulated. Are these mutations mutually exclusive? In a recent analysis of $\sim 150$ primary breast tumors, coexistence of low PTEN levels and PI3K mutations was rare and only detected in two cases [65]. This suggests that following mutation/activation of PI3K or loss of PTEN during the genesis of breast cancer, either of which results in an increase in PIP3 levels, there is no selective advantage for mutation of the other gene. However, it should be mentioned that in a study of 66 endometrial cancers, PI3K mutations were more common in tumors with PTEN mutations (46 vs. 24\%) [66]. Thus, there might be tumor type differences in the prevalence of both alterations.

TSC is a tumor suppressor syndrome with a broad spectrum of clinical manifestations, including benign hamartomas that occur in a wide variety of tissues such as brain, skin, heart and kidneys [67]. As discussed above, TSC negatively regulates mTOR activity. Hence, mTOR signaling has been shown to be overactive in primary cells derived from hamartomas in TSC patients [68] supporting the functional relationship between the hyperproliferative disease and mTOR activation. Mutations or LOH in TSC1 and TSC2 are associated with TSC syndrome [69]. In addition to hamartomas, TSC patients have an increased risk of developing renal cell carcinoma. Recently, expression of TSC proteins has also been studied in breast cancers [70]. RNA pooled from 120 primary tumors had $\sim 80 \%$ decrease in hamartin specific transcripts compared to the level observed in normal breast tissue. Although there were no changes in tuberin RNA levels in the same set, the $T S C 1$ gene promoter was found to be heavily methylated in some breast cancer cell lines [70], suggesting that this tumor suppressor might be controlled by epigenetic mechanisms. It will be important to examine the expression levels of TSC proteins in more sets of tumors to know how frequently these proteins are targeted in breast cancer. 
Germline inactivating mutations in $L K B 1 / S T K 11$ encoding the $\mathrm{LKB} 1 /$ serine threonine kinase 11 are responsible for PJS [36], an autosomal dominant syndrome characterized by benign hamartomatous polyps in the gastrointestinal tract [38]. The LKB1 kinase has also been implicated in sporadic human cancer since it has been found that about $30 \%$ of lung adenocarcinomas show somatic inactivating mutations in the LKB1 gene [71]. Patients with PJS have an increased risk for development of a variety of cancers, including breast [38, 72]; there is one report of a germline $L K B 1$ mutation in breast cancer [73]. Inactivating mutations in LKB1 have not been reported in a screen of 518 kinases (the kinome) in 25 sporadic breast cancers [74]. However, an examination of 140 primary breast tumors, revealed that $30 \%$ had a genomic deletion in the chromosomal region including LKB1 (19p13.2-13.3) [75]. Although follow-up studies examining the level of LKB1 protein will be necessary, these results suggest that AMPK activation might be deregulated in breast cancer. This alteration could have an important impact on mTOR, for example, keeping it active under hypoxic conditions, when mTOR is normally down-regulated [76].

\section{Downstream Targets of $\mathrm{mTOR}$ in Cancer}

A number of mTOR translational targets are known to be activated and overexpressed in cancer and are involved in the transformation process as well as in drug resistance. For example, eIF-4E is overexpressed in a variety of human cancers, triggers tumor formation in vivo [77] and mediates Aktand mTOR-dependent survival and drug resistance in a murine lymphoma model [78]. Cyclin D1, another mTOR target [79] is overexpressed in many primary breast tumors. These findings indicate, therefore, that targets downstream of mTOR are also worth exploiting in cancer treatment.

These results point to the importance of aberrant mTOR activity, and presumably alterations in translational control, in driving the malignant phenotype. Indeed this was demonstrated very elegantly in a study of a glioma tumor model, where total mRNA profiles or polysomal mRNA profiles were examined after the PI3K pathway was inhibited. The major effect of blocking this pathway was seen at the translational and not the transcriptional level [80]. There was a major shift in the polysome occupancy of mRNAs encoding proteins involved in proliferation and growth.

\section{Targeting the mTOR-Raptor Pathway in Cancer}

The mTOR-Raptor pathway is aberrantly activated in many human cancers. Thus, approaches to block the pathway are being actively pursued in many laboratories and pharmaceutical companies. In view of the multiple regulators of
mTOR, there are a number of target proteins for which intervention would be predicted to lower mTOR activity and have an impact on cancer (Table 1).

Considering the broad experience gained in the 20 years since small molecule kinase inhibitors were described [81, 82], the pathway kinases PI3K, Akt and mTOR are appealing targets. (Inhibition of LKB1 is not desirable since this would promote mTOR activation). Furthermore, a number of inhibitors blocking the cancer promoting RTKs that contribute to PI3K pathway activation are already in the clinic [83-85]. Despite major interest in the pathway, no drugs directly targeting PI3K or Akt have entered cancer trials; however, a number are in preclinical development (reviewed in [86]). Two well characterized inhibitors of PI3K activity, LY294002 and wortmannin, have been tested in numerous models of cancer and shown to have antitumor activity both in vitro and in vivo. While these compounds are not suitable for human studies, these data provide compelling evidence that targeting this pathway should impact on human cancer [87].

Farnesyltransferase inhibitors (FTIs) are another interesting class of therapeutics to consider as mTOR pathway inhibitors. Substrates for farnesyltransferase are proteins with a C-terminal CAAX motif, including Ras family members. FTIs were originally designed to block the action of Ras oncoproteins, since they require a farnesyl isoprenoid membrane anchor for correct cellular activity [88]. Various lines of evidence suggest that the anti-tumor effect of FTIs is dependent upon blocking the activity of other cellular proteins. Rheb, the upstream activator of mTOR is post-translationally modified by lipids [56] and is a strong candidate for the anti-proliferative activity of FTIs in cancer models [34, 56].

Table 1 Inhibitors targeting the mTOR pathway in preclinical or clinical development.

\begin{tabular}{llcl}
\hline Target & Phase & Compound & Company \\
\hline mTOR & II & $\begin{array}{c}\text { Everolimus } \\
\text { (RAD001) }\end{array}$ & Novartis \\
& II/III & $\begin{array}{c}\text { Temsirolimus } \\
\text { (CCI-779) }\end{array}$ & Wyeth \\
& I/II & $\begin{array}{c}\text { AP-23573 } \\
\text { Gefitinib }\end{array}$ & Ariad \\
& Approved & AstraZeneca \\
ErbB1 & Approved & $\begin{array}{c}\text { Erlotinib } \\
\text { (Tarceva) }\end{array}$ & Genentech \\
& I & AEE778 & Novartis \\
& Preclinical & & \\
ErbB1/ErbB2/ & Preclinical & lonafarnib & Schering- \\
VEGF & II/III & (SCH66336) & Plough \\
PI3K & & tipifarnib & OrthoBiotech \\
Akt & (R115777) & \\
Farnesyltransferase & & & \\
& & &
\end{tabular}


Several FTIs are in clinical development (reviewed in [5]). Some of these are being tested in breast cancer models [56], and encouraging results have been obtained in a phase I clinical trial on the FTI tipifarnib when given to advanced breast cancer patients in combination with tamoxifen [89].

\section{mTOR Inhibitors}

The mTOR kinase is a target for rapamycin analogs, several of which have been approved for use in transplant patients as immunosuppressants [3]. Rapamycin and its derivatives temsirolimus (CCI-779) [90], everolimus (RAD001) [91] and AP-23573 [92], all of which are in clinical development (reviewed in [5, 92]), inhibit mTOR kinase by binding the FK506-binding protein-12 (FKBP12). The mechanism by which this complex blocks mTOR activity is still under investigation (discussed in [11]), and some experiments suggest that FKBP12-rapamycin blocks access of mTOR substrates to the complex [13]. Importantly, rapamycins inhibit the mTOR-Raptor complex functions specifically; the mTORrictor complex being insensitive to acute exposure to this class of inhibitors [16].

Rapamycin analogues show some clinical activity, however, not on all patients. Thus, the current clinical challenge is to determine markers that can help predict sensitivity to mTOR inhibition in order to assist in selecting the appropriate patients for therapy. In this respect, animal models of cancer might be helpful in making some predictions. In a mouse model, the prostate was shown to be particularly sensitive to PTEN levels, which dictate Akt activation and cancer development [93]. Furthermore, an Akt driven transgenic prostate tumor model was effectively treated with the mTOR inhibitor RAD001 [94]. A phase II clinical trial of the mTOR inhibitor CCI-779 in prostate cancer was initiated; however, no results have been published (discussed in [95]).

Preclinical studies suggest that breast tumor cells might be particularly sensitive to mTOR inhibitors [21, 96]. As mentioned above, PTEN is frequently altered in breast cancers, suggesting that PTEN levels might predict sensitivity to rapamycins. Although PTEN deficiency has been correlated with increased sensitivity to mTOR inhibitors in many tumor models, including glioblastoma or multiple myeloma [97, 98], a similar trend has not been observed in breast tumor cell lines $[21,96]$, presumably because a number of other alterations specifically driving breast cancer development are feeding into the Akt/mTOR pathway. Nevertheless, in a phase II safety trial of CCI-779 in women with advanced breast cancer three of the four patients with PTEN deficient tumors showed objective responses to treatment, while only $37 \%$ of the overall patient population $(n=28)$ experienced clinical benefit, supporting the idea that patients with PTEN deficient breast tumors might benefit from treatment with mTOR inhibitors.
ErbB2 is frequently overexpressed in breast cancers and is correlated with poor clinical prognosis. ErbB2 overexpression provides a strong stimulus for PI3K/Akt pathway activation and has been associated with increased phosphorylation of mTOR effectors in primary breast cancers [99, 100], indicating that ErbB2-driven tumors might be more dependent on mTOR signaling. Indeed, in the abovementioned phase II safety trial, 2 of 3 ErbB2-overexpressing patients showed an objective response to the rapamycin analogue, indicating that ErbB2 overexpression might be a marker for choosing patients to treat with mTOR inhibitors.

The estrogen receptor (ER) has recently emerged as a potential stratification marker for an increased antitumor benefit to rapamycins in combination with endocrine therapy. The ER is an important predictive and prognostic marker in human breast cancer, being expressed in about $60 \%$ of breast cancers. It has become evident that estrogen/ ER signaling exhibits pleiotropic effects through nongenomic interactions with growth factor signaling pathways. In particular, long-term estrogen-deprived breast tumor cells exhibit increased Akt/mTOR activation [101]. Moreover, the pathway has been strongly implicated in resistance to antiestrogen therapeutics (Reviewed in [102]). Thus, a number of preclinical studies combining rapamycins with endocrine therapies supported the potential for these combinations for the therapy of endocrine-dependent breast cancers [103, 104].

The rationale to evaluate the above-mentioned markers as potential predisposition markers is strong in breast cancer patients. Importantly, all these alterations and resistance mechanisms impinge on Akt signaling, eventually leading to increased dependence on mTOR for tumor cell survival and/or tumor progression. This rationale supports the possibility that tumors bearing any alterations associated with increased activated Akt levels should be particularly sensitive to mTOR inhibition.

Acknowledgments We thank Dr. Brian Hemmings of the FMI for his helpful suggestions. The laboratory of N.E.H. was supported by Novartis Forschungsstiftung Zweigniederlassung Friedrich Miescher Institute.

\section{References}

1. Heitman J, Movva NR, Hall MN. Targets for cell cycle arrest by the immunosuppressant rapamycin in yeast. Science 1991;253: 905-9.

2. Calne RY, Collier DS, Lim S, Pollard SG, Samaan A, White DJ, Thiru S. Rapamycin for immunosuppression in organ allografting. Lancet 1989;2:227.

3. Saunders RN, Metcalfe MS, Nicholson ML. Rapamycin in transplantation: a review of the evidence. Kidney Int 2001;59:3-16.

4. Bjornsti MA, Houghton PJ. The TOR pathway: a target for cancer therapy. Nat Rev Cancer 2004;4:335-48. 
5. Johnston SR. Clinical trials of intracellular signal transductions inhibitors for breast cancer - a strategy to overcome endocrine resistance. Endocr Relat Cancer 2005;12(Suppl 1):S145-57.

6. Abraham RT. PI 3-kinase related kinases: 'big' players in stressinduced signaling pathways. DNA Repair (Amst) 2004;3:88387.

7. Hara K, Yonezawa K, Weng QP, Kozlowski MT, Belham C, Avruch J. Amino acid sufficiency and mTOR regulate p70 S6 kinase and eIF-4E BP1 through a common effector mechanism. J Biol Chem 1998;273:14484-94.

8. Shaw RJ, Bardeesy N, Manning BD, Lopez L, Kosmatka M, DePinho RA, Cantley LC. The LKB1 tumor suppressor negatively regulates mTOR signaling. Cancer Cells 2004;6:91-9.

9. Brugarolas J, Lei K, Hurley RL, Manning BD, Reiling JH, Hafen E, Witters LA, Ellisen LW, Kaelin WG, Jr. Regulation of mTOR function in response to hypoxia by REDD1 and the TSC1/TSC2 tumor suppressor complex. Genes Dev 2004;18:2893-904.

10. Cantley LC. The phosphoinositide 3-kinase pathway. Science 2002;296:1655-7.

11. Wullschleger S, Loewith R, Hall MN. TOR Signaling in growth and metabolism. Cell 2006;124:471-84.

12. Hara K, Maruki Y, Long X, Yoshino K, Oshiro N, Hidayat S, Tokunaga C, Avruch J, Yonezawa K. Raptor, a binding partner of target of rapamycin (TOR), mediates TOR action. Cell 2002;110: 177-89.

13. Kim DH, Sarbassov DD, Ali SM, King JE, Latek RR, Erdjument-Bromage H, Tempst P, Sabatini DM. mTOR interacts with raptor to form a nutrient-sensitive complex that signals to the cell growth machinery. Cell 2002;110:163-75.

14. Schalm SS, Fingar DC, Sabatini DM, Blenis J. TOS motifmediated raptor binding regulates 4E-BP1 multisite phosphorylation and function. Curr Biol 2003;13:797-806.

15. Jacinto E, Loewith R, Schmidt A, Lin S, Ruegg MA, Hall A, Hall MN. Mammalian TOR complex 2 controls the actin cytoskeleton and is rapamycin insensitive. Nat Cell Biol 2004; 6:1122-8.

16. Sarbassov DD, Ali SM, Kim DH, Guertin DA, Latek RR, Erdjument-Bromage H, Tempst P, Sabatini DM. Rictor, a novel binding partner of mTOR, defines a rapamycin-insensitive and raptor-independent pathway that regulates the cytoskeleton. Curr Biol 2004;14:1296-302.

17. Gingras AC, Raught B, Sonenberg N. Regulation of translation initiation by FRAP/mTOR. Genes Dev 2001;15:807-26.

18. Mothe-Satney I, Brunn GJ, McMahon LP, Capaldo CT, Abraham RT, Lawrence JC, Jr. Mammalian target of rapamycin-dependent phosphorylation of PHAS-I in four (S/T)P sites detected by phospho-specific antibodies. J Biol Chem 2000;275:33836-43.

19. West MJ, Stoneley M, Willis AE. Translational induction of the c-myc oncogene via activation of the FRAP/TOR signalling pathway. Oncogene 1998;17:769-80.

20. Koziczak M, Holbro T, Hynes NE. Blocking of FGFR signaling inhibits breast cancer cell proliferation through downregulation of D-type cyclins. Oncogene 2004;23:3501-8.

21. Noh WC, Mondesire WH, Peng J, Jian W, Zhang H, Dong J, Mills GB, Hung MC, Meric-Bernstam F. Determinants of rapamycin sensitivity in breast cancer cells. Clin Cancer Res 2004;10:1013-23.

22. Gera JF, Mellinghoff IK, Shi Y, Rettig MB, Tran C, Hsu JH, Sawyers CL, Lichtenstein AK. AKT activity determines sensitivity to mammalian target of rapamycin (mTOR) inhibitors by regulating cyclin D1 and c-myc expression. J Biol Chem 2004; 279:2737-46.

23. Meyuhas O. Synthesis of the translational apparatus is regulated at the translational level. Eur J Biochem 2000;267:6321-30.

24. Alessi DR, Sakamoto K, Bayascas JR. LKB1-Dependent signaling pathways. Ann Rev Biochem 2006.
25. Hardie DG, Scott JW, Pan DA, Hudson ER. Management of cellular energy by the AMP-activated protein kinase system. FEBS Lett 2003;546:113-20.

26. Hay N. The Akt-mTOR tango and its relevance to cancer. Cancer Cells 2005;8:179-83.

27. Brazil DP, Hemmings BA. Ten years of protein kinase B signalling: a hard Akt to follow. Trends Biochem Sci 2001;26: 657-64.

28. Dong LQ, Liu F. PDK2: the missing piece in the receptor tyrosine kinase signaling pathway puzzle. Am J Physiol Endocrinol Metab 2005;289:E187-96.

29. Tee AR, Fingar DC, Manning BD, Kwiatkowski DJ, Cantley LC, Blenis J. Tuberous sclerosis complex-1 and -2 gene products function together to inhibit mammalian target of rapamycin (mTOR)-mediated downstream signaling. Proc Natl Acad Sci USA 2002;99:13571-6.

30. Inoki $\mathrm{K}, \mathrm{Li} \mathrm{Y,} \mathrm{Xu} \mathrm{T,} \mathrm{Guan} \mathrm{KL.} \mathrm{Rheb} \mathrm{GTPase} \mathrm{is} \mathrm{a} \mathrm{direct} \mathrm{target} \mathrm{of}$ TSC2 GAP activity and regulates mTOR signaling. Genes Dev 2003; 17:1829-34.

31. Garami A, Zwartkruis FJ, Nobukuni T, Joaquin M, Roccio M, Stocker H, Kozma SC, Hafen E, Bos JL, Thomas G. Insulin activation of Rheb, a mediator of mTOR/S6K/4E-BP signaling, is inhibited by TSC1 and 2. Mol Cell 2003;11:1457-66.

32. Inoki $\mathrm{K}, \mathrm{Li} \mathrm{Y}, \mathrm{Zhu} \mathrm{T}$, Wu J, Guan KL. TSC2 is phosphorylated and inhibited by Akt and suppresses mTOR signalling. Nat Cell Biol 2002;4:648-57.

33. Potter CJ, Pedraza LG, Xu T. Akt regulates growth by directly phosphorylating Tsc2. Nat Cell Biol 2002;4:658-65.

34. Castro AF, Rebhun JF, Clark GJ, Quilliam LA. Rheb binds tuberous sclerosis complex 2 (TSC2) and promotes S6 kinase activation in a rapamycin- and farnesylation-dependent manner. J Biol Chem 2003;278:32493-6.

35. Long X, Lin Y, Ortiz-Vega S, Yonezawa K, Avruch J. Rheb binds and regulates the mTOR kinase. Curr Biol 2005;15:702-13.

36. Hemminki A, Markie D, Tomlinson I, Avizienyte E, Roth S, Loukola A, Bignell G, Warren W, Aminoff M, Hoglund P, Jarvinen H, Kristo P, Pelin K, Ridanpaa M, Salovaara R, Toro T, Bodmer W, Olschwang S, Olsen AS, Stratton MR, de la Chapelle A, Aaltonen LA. A serine/threonine kinase gene defective in Peutz-Jeghers syndrome. Nature 1998;391:184-7.

37. Jenne DE, Reimann H, Nezu J, Friedel W, Loff S, Jeschke R, Muller O, Back W, Zimmer M. Peutz-Jeghers syndrome is caused by mutations in a novel serine threonine kinase. Nat Genet 1998; 18:38-43.

38. Giardiello FM, Welsh SB, Hamilton SR, Offerhaus GJ, Gittelsohn AM, Booker SV, Krush AJ, Yardley JH, Luk GD. Increased risk of cancer in the Peutz-Jeghers syndrome. N Engl J Med 1987;316: 1511-4.

39. Hawley SA, Boudeau J, Reid JL, Mustard KJ, Udd L, Makela TP, Alessi DR, Hardie DG. Complexes between the LKB1 tumor suppressor, STRAD alpha/beta and MO25 alpha/beta are upstream kinases in the AMP-activated protein kinase cascade. J Biol 2003;2:28.

40. Inoki $\mathrm{K}, \mathrm{Zhu} \mathrm{T}$, Guan KL. TSC2 mediates cellular energy response to control cell growth and survival. Cell 2003;115:57790.

41. Baserga R. The insulin-like growth factor-I receptor as a target for cancer therapy. Expert Opin Ther Targets 2005;9:753-68.

42. Penault-Llorca F, Bertucci F, Adelaide J, Parc P, Coulier F, Jacquemier J, Birnbaum D, deLapeyriere O. Expression of FGF and FGF receptor genes in human breast cancer. Int $\mathrm{J}$ Cancer 1995;61:170-6.

43. Bange J, Prechtl D, Cheburkin Y, Specht K, Harbeck N, Schmitt M, Knyazeva T, Muller S, Gartner S, Sures I, Wang H, Imyanitov E, Haring HU, Knayzev P, Iacobelli S, Hofler H, Ullrich A. Cancer progression and tumor cell motility are asso- 
ciated with the FGFR4 $\operatorname{Arg}(388)$ allele. Cancer Res 2002;62: $840-7$.

44. Holbro T, Hynes NE. ErbB receptors: directing key signaling networks throughout life. Annu Rev Pharmacol Toxicol 2004; $44: 195-217$.

45. Holbro T, Beerli RR, Maurer F, Koziczak M, Barbas CF, III, Hynes NE. The ErbB2/ErbB3 heterodimer functions as an oncogenic unit: ErbB2 requires ErbB3 to drive breast tumor cell proliferation. Proc Natl Acad Sci USA 2003;100:8933-8.

46. Prigent SA, Gullick WJ. Identification of c-erbB-3 binding sites for phosphatidylinositol 3'-kinase and SHC using an EGF receptor/c-erbB-3 chimera. Embo J 1994;13:2831-41.

47. Shayesteh L, Lu Y, Kuo WL, Baldocchi R, Godfrey T, Collins C, Pinkel D, Powell B, Mills GB, Gray JW. PIK3CA is implicated as an oncogene in ovarian cancer. Nat Genet 1999;21:99-102.

48. Samuels Y, Wang Z, Bardelli A, Silliman N, Ptak J, Szabo S, Yan H, Gazdar A, Powell SM, Riggins GJ, Willson JK, Markowitz S, Kinzler KW, Vogelstein B, Velculescu VE. High frequency of mutations of the PIK3CA gene in human cancers. Science 2004; 304:554.

49. Bachman KE, Argani P, Samuels Y, Silliman N, Ptak J, Szabo S, Konishi H, Karakas B, Blair BG, Lin C, Peters BA, Velculescu VE, Park BH. The PIK3CA gene is mutated with high frequency in human breast cancers. Cancer Biolther 2004;3:772-5.

50. Kang S, Bader AG, Vogt PK. Phosphatidylinositol 3-kinase mutations identified in human cancer are oncogenic. Proc Natl Acad Sci USA 2005;102:802-7.

51. Zhao JJ, Liu Z, Wang L, Shin E, Loda MF, Roberts TM. The oncogenic properties of mutant p110alpha and p110beta phosphatidylinositol 3-kinases in human mammary epithelial cells. Proc Natl Acad Sci USA 2005;102:18443-8.

52. Sun M, Wang G, Paciga JE, Feldman RI, Yuan ZQ, Ma XL, Shelley SA, Jove R, Tsichlis PN, Nicosia SV, Cheng JQ. AKT1/ PKBalpha kinase is frequently elevated in human cancers and its constitutive activation is required for oncogenic transformation in NIH3T3 cells. Am J Pathol 2001;159:431-7.

53. Sun M, Paciga JE, Feldman RI, Yuan Z, Coppola D, Lu YY, Shelley SA, Nicosia SV, Cheng JQ. Phosphatidylinositol-3-OH Kinase (PI3K)/AKT2, activated in breast cancer, regulates and is induced by estrogen receptor alpha (ERalpha) via interaction between ERalpha and PI3K. Cancer Res 2001;61:5985-91.

54. Parsons DW, Wang TL, Samuels Y, Bardelli A, Cummins JM, DeLong L, Silliman N, Ptak J, Szabo S, Willson JK, Markowitz S, Kinzler KW, Vogelstein B, Lengauer C, Velculescu VE. Colorectal cancer: mutations in a signalling pathway. Nature 2005; 436:792.

55. Bellacosa A, de Feo D, Godwin AK, Bell DW, Cheng JQ, Altomare DA, Wan M, Dubeau L, Scambia G, Masciullo V, et al. Molecular alterations of the AKT2 oncogene in ovarian and breast carcinomas. Int J Cancer 1995;64:280-5.

56. Basso AD, Mirza A, Liu G, Long BJ, Bishop WR, Kirschmeier P. The farnesyl transferase inhibitor (FTI) SCH66336 (lonafarnib) inhibits Rheb farnesylation and mTOR signaling. Role in FTI enhancement of taxane and tamoxifen anti-tumor activity. J Biol Chem 2005;280:31101-8.

57. Wu GJ, Sinclair, CS, Paape J, Ingle JN, Roche PC, James CD, Couch FJ. 17q23 amplifications in breast cancer involve the PAT1, RAD51C, PS6K, and SIGma1B genes. Cancer Res 2000;60:5371-5.

58. Barlund M, Forozan F, Kononen J, Bubendorf L, Chen Y, Bittner ML, Torhorst J, Haas P, Bucher C, Sauter G, Kallioniemi OP, Kallioniemi A. Detecting activation of ribosomal protein S6 kinase by complementary DNA and tissue microarray analysis. J Natl Cancer Inst 2000;92:1252-9.

59. Feilotter HE, Coulon V, McVeigh JL, Boag AH, Dorion-Bonnet F, Duboue B, Latham WC, Eng C, Mulligan LM, Longy M. Analysis of the 10q23 chromosomal region and the PTEN gene in human sporadic breast carcinoma. Br J Cancer 1999;79:718-23.

60. Rhei E, Kang L, Bogomolniy F, Federici MG, Borgen PI, Boyd J. Mutation analysis of the putative tumor suppressor gene PTEN/ MMAC1 in primary breast carcinomas. Cancer Res 1997;57: 3657-9.

61. Singh B, Ittmann MM, Krolewski JJ. Sporadic breast cancers exhibit loss of heterozygosity on chromosome segment 10q23 close to the Cowden disease locus. Genes Chromosomes Cancer 1998;21:166-71.

62. Garcia JM, Silva J, Pena C, Garcia V, Rodriguez R, Cruz MA, Cantos B, Provencio M, Espana P, Bonilla, F. Promoter methylation of the PTEN gene is a common molecular change in breast cancer. Genes Chromosomes Cancer 2004;41:117-24.

63. Perren A, Weng LP, Boag AH, Ziebold U, Thakore K, Dahia PL, Komminoth P, Lees JA, Mulligan LM, Mutter GL, Eng C. Immunohistochemical evidence of loss of PTEN expression in primary ductal adenocarcinomas of the breast. Am J Pathol 1999; 155:1253-60.

64. Tsutsui S, Inoue H, Yasuda K, Suzuki K, Higashi H, Era S, Mori M. Reduced expression of PTEN protein and its prognostic implications in invasive ductal carcinoma of the breast. Oncology 2005;68:398-404.

65. Saal LH, Holm K, Maurer M, Memeo L, Su T, Wang X, Yu JS, Malmstrom PO, Mansukhani M, Enoksson J, Hibshoosh H, Borg A, Parsons R. PIK3CA mutations correlate with hormone receptors, node metastasis, and ERBB2, and are mutually exclusive with PTEN loss in human breast carcinoma. Cancer Res 2005; 65:2554-9.

66. Oda K, Stokoe D, Taketani Y, McCormick F. High frequency of coexistent mutations of PIK3CA and PTEN genes in endometrial carcinoma. Cancer Res 2005;65:10669-73.

67. Astrinidis A, Henske EP. Tuberous sclerosis complex: linking growth and energy signaling pathways with human disease. Oncogene 2005;24:7475-81.

68. Kenerson HL, Aicher LD, True LD, Yeung RS. Activated mammalian target of rapamycin pathway in the pathogenesis of tuberous sclerosis complex renal tumors. Cancer Res 2002;62: 5645-50.

69. Cheadle JP, Reeve MP, Sampson JR, Kwiatkowski DJ. Molecular genetic advances in tuberous sclerosis. Hum Genet 2000; 107:97-114.

70. Jiang WG, Sampson J, Martin TA, Lee-Jones L, Watkins G, Douglas-Jones A, Mokbel K, Mansel RE. Tuberin and hamartin are aberrantly expressed and linked to clinical outcome in human breast cancer: the role of promoter methylation of TSC genes. Eur J Cancer 2005;41:1628-36.

71. Sanchez-Cespedes M, Parrella P, Esteller M, Nomoto S, Trink B, Engles JM, Westra WH, Herman JG, Sidransky D. Inactivation of LKB1/STK11 is a common event in adenocarcinomas of the lung. Cancer Res 2002;62:3659-62.

72. Boardman LA, Thibodeau SN, Schaid DJ, Lindor NM, McDonnell SK, Burgart LJ, Ahlquist DA, Podratz KC, Pittelkow M, Hartmann LC. Increased risk for cancer in patients with the Peutz-Jeghers syndrome. Ann Intern Med 1998;128:896-9.

73. Nakanishi C, Yamaguchi T, Iijima T, Saji S, Toi M, Mori T, Miyaki M. Germline mutation of the LKB1/STK11 gene with loss of the normal allele in an aggressive breast cancer of PeutzJeghers syndrome. Oncology 2004;67:476-9.

74. Stephens P, Edkins S, Davies H, Greenman C, Cox C, Hunter C, Bignell G, Teague J, Smith R, Stevens C, O'Meara S, Parker A, Tarpey P, Avis T, Barthorpe A, Brackenbury L, Buck G, Butler A, Clements J, Cole J, Dicks E, Edwards K, Forbes S, Gorton M, Gray K, Halliday K, Harrison R, Hills K, Hinton J, Jones D, Kosmidou V, Laman R, Lugg R, Menzies A, Perry J, Petty R, Raine K, Shepherd R, Small A, Solomon H, Stephens Y, Tofts C, Varian J, Webb A, West S, Widaa S, Yates A, Brasseur F, 
Cooper CS, Flanagan AM, Green A, Knowles M, Leung SY, Looijenga LH, Malkowicz B, Pierotti MA, Teh B, Yuen ST, Nicholson AG, Lakhani S, Easton DF, Weber BL, Stratton MR, Futreal PA, Wooster R. A screen of the complete protein kinase gene family identifies diverse patterns of somatic mutations in human breast cancer. Nat Genet 2005;37:590-2.

75. Yang TL, Su YR, Huang CS, Yu JC, Lo YL, Wu PE, Shen CY. High-resolution 19p13.2-13.3 allelotyping of breast carcinomas demonstrates frequent loss of heterozygosity. Genes Chromosomes Cancer 2004;41:250-6.

76. Hudson CC, Liu M, Chiang GG, Otterness DM, Loomis DC, Kaper F, Giaccia AJ, Abraham RT. Regulation of hypoxiainducible factor 1 alpha expression and function by the mammalian target of rapamycin. Mol Cell Biol 2002;22:7004-14.

77. Ruggero D, Montanaro L, Ma L, Xu W, Londei P, CordonCardo C, Pandolfi PP. The translation factor eIF-4E promotes tumor formation and cooperates with c-Myc in lymphomagenesis. Nat Med 2004;10:484-6.

78. Wendel HG, De Stanchina E, Fridman JS, Malina A, Ray S, Kogan S, Cordon-Cardo C, Pelletier J, Lowe SW. Survival signalling by Akt and eIF4E in oncogenesis and cancer therapy. Nature 2004;428:332-7.

79. Koziczak M, Hynes NE. Cooperation between fibroblast growth factor receptor-4 and ErbB2 in regulation of cyclin D1 translation. J Biol Chem 2004;279:50004-11.

80. Rajasekhar VK, Viale A, Socci ND, Wiedmann M, Hu X, Holland EC. Oncogenic Ras and Akt signaling contribute to glioblastoma formation by differential recruitment of existing mRNAs to polysomes. Mol Cell 2003;12:889-901.

81. Tamaoki T, Nomoto H, Takahashi I, Kato Y, Morimoto M, Tomita F. Staurosporine, a potent inhibitor of phospholipid/ $\mathrm{Ca}++$ dependent protein kinase. Biochem Biophys Res Commun 1986; 135:397-402.

82. Gazit A, Yaish P, Gilon C, Levitzki A. Tyrphostins I: synthesis and biological activity of protein tyrosine kinase inhibitors. J Med Chem 1989;32:2344-52.

83. Hynes NE, Lane HA. ERBB receptors and cancer: the complexity of targeted inhibitors. Nat Rev Cancer 2005;5:341-54.

84. Chen J, Lee BH, Williams IR, Kutok JL, Mitsiades CS, Duclos N, Cohen S, Adelsperger J, Okabe R, Coburn A, Moore S, Huntly BJ, Fabbro D, Anderson KC, Griffin JD, Gilliland DG. FGFR3 as a therapeutic target of the small molecule inhibitor PKC412 in hematopoietic malignancies. Oncogene 2005; 24:8259-67.

85. Borzilleri RM, Zheng X, Qian L, Ellis C, Cai ZW, Wautlet BS, Mortillo S, Jeyaseelan R, Sr., Kukral DW, Fura A, Kamath A, Vyas V, Tokarski JS, Barrish JC, Hunt JT, Lombardo LJ, Fargnoli J, Bhide RS. Design, synthesis, and evaluation of orally active 4(2,4-difluoro-5-(methoxycarbamoyl)phenylamino)pyrrolo[2,1-f] $[1,2,4]$ triaz ines as dual vascular endothelial growth factor receptor-2 and fibroblast growth factor receptor-1 inhibitors. J Med Chem 2005;48:3991-4008.

86. Hennessy BT, Smith DL, Ram PT, Lu Y, Mills GB. Exploiting the PI3K/AKT pathway for cancer drug discovery. Nat Rev Drug Discov 2005;4:988-1004.

87. Granville CA, Memmott RM, Gills JJ, Dennis PA. Handicapping the race to develop inhibitors of the phosphoinositide 3-kinase/ Akt/mammalian target of rapamycin pathway. Clin Cancer Res 2006;12:679-89.

88. Sebti SM, Adjei AA. Farnesyltransferase inhibitors. Semin Oncol 2004;31:28-39.

89. Lebowitz PF, Eng-Wong J, Widemann BC, Balis FM, Jayaprakash N, Chow C, Clark G, Gantz SB, Venzon D, Zujewski J. A phase I trial and pharmacokinetic study of tipifarnib, a farnesyltransferase inhibitor, and tamoxifen in metastatic breast cancer. Clin Cancer Res 2005;11:1247-52.

90. Peralba JM, DeGraffenried L, Friedrichs W, Fulcher L, Grunwald V, Weiss G, Hidalgo M. Pharmacodynamic evaluation of CCI779 , an inhibitor of mTOR, in cancer patients. Clin Cancer Res 2003;9:2887-92.

91. Boulay A, Zumstein-Mecker S, Stephan C, Beuvink I, Zilbermann F, Haller R, Tobler S, Heusser C, O’Reilly T, Stolz B, Marti A, Thomas G, Lane HA. Antitumor efficacy of intermittent treatment schedules with the rapamycin derivative RAD001 correlates with prolonged inactivation of ribosomal protein S6 kinase 1 in peripheral blood mononuclear cells. Cancer Res 2004;64: 252-61.

92. Dancey JE. Inhibitors of the mammalian target of rapamycin. Expert Opin Investig Drugs 2005;14:313-28.

93. Trotman LC, Niki M, Dotan ZA, Koutcher JA, Di Cristofano A, Xiao A, Khoo AS, Roy-Burman P, Greenberg NM, Van Dyke T, Cordon-Cardo C, Pandolfi PP. Pten dose dictates cancer progression in the prostate. PLoS Biol 2003;1:E59.

94. Majumder PK, Febbo PG, Bikoff R, Berger R, Xue Q, McMahon LM, Manola J, Brugarolas J, McDonnell TJ, Golub TR, Loda M, Lane HA, Sellers WR. mTOR inhibition reverses Akt-dependent prostate intraepithelial neoplasia through regulation of apoptotic and HIF-1-dependent pathways. Nat Med 2004; 10:594-601.

95. Majumder PK, Sellers WR. Akt-regulated pathways in prostate cancer. Oncogene 2005;24:7465-74.

96. Yu K, Toral-Barza L, Discafani C, Zhang WG, Skotnicki J, Frost P, Gibbons JJ. mTOR, a novel target in breast cancer: the effect of CCI-779, an mTOR inhibitor, in preclinical models of breast cancer. Endocr Relat Cancer 2001;8:249-58.

97. Neshat MS, Mellinghoff IK, Tran C, Stiles B, Thomas G, Petersen R, Frost P, Gibbons JJ, Wu H, Sawyers CL. Enhanced sensitivity of PTEN-deficient tumors to inhibition of FRAP/ mTOR. Proc Natl Acad Sci USA 2001;98:10314-9.

98. Shi Y, Gera J, Hu L, Hsu JH, Bookstein R, Li W, Lichtenstein A. Enhanced sensitivity of multiple myeloma cells containing PTEN mutations to CCI-779. Cancer Res 2002;62:5027-34.

99. Zhou X, Tan M, Stone Hawthorne V, Klos KS, Lan KH, Yang Y, Yang W, Smith TL, Shi D, Yu D. Activation of the Akt/ mammalian target of rapamycin/4E-BP1 pathway by ErbB2 overexpression predicts tumor progression in breast cancers. Clin Cancer Res 2004;10:6779-88.

100. Klos KS, Wyszomierski SL, Sun M, Tan M, Zhou X, Li P, Yang W, Yin G, Hittelman WN, Yu D. ErbB2 increases vascular endothelial growth factor protein synthesis via activation of mammalian target of rapamycin $/ \mathrm{p} 70 \mathrm{~S} 6 \mathrm{~K}$ leading to increased angiogenesis and spontaneous metastasis of human breast cancer cells. Cancer Res 2006;66:2028-37.

101. Santen RJ, Song RX, Zhang Z, Kumar R, Jeng MH, Masamura A, Lawrence J, Jr., Berstein L, Yue W. Long-term estradiol deprivation in breast cancer cells up-regulates growth factor signaling and enhances estrogen sensitivity. Endocr Relat Cancer 2005;12 Suppl 1:S61-73.

102. Johnston SR. Combinations of endocrine and biological agents: present status of therapeutic and presurgical investigations. Clin Cancer Res 2005;11:889s-99s.

103. deGraffenried LA, Friedrichs WE, Russell DH, Donzis EJ, Middleton AK, Silva JM, Roth RA, Hidalgo M. Inhibition of mTOR activity restores tamoxifen response in breast cancer cells with aberrant Akt Activity. Clin Cancer Res 2004;10:8059-67.

104. Boulay A, Rudloff J, Ye J, Zumstein-Mecker S, O’Reilly T, Evans DB, Chen S, Lane HA. Dual inhibition of mTOR and estrogen receptor signaling in vitro induces cell death in models of breast cancer. Clin Cancer Res 2005;11:5319-28. 